\title{
Aphid-plant interactions affect the suitability of Myzus spp. as prey for the two spot ladybird, Adalia bipunctata (Coleoptera: Coccinellidae)
}

\author{
Mohammad A. JALALI ${ }^{1}$ and J.P. MICHAUD ${ }^{2 *}$ \\ ${ }^{1}$ Department of Crop Protection, Agriculture College, Vali-e-Asr University of Rafsanjan, Rafsanjan, Iran \\ ${ }^{2}$ Agricultural Research Center-Hays, Department of Entomology, $1232240^{\text {th }}$ Ave., Hays, Kansas, 67601, USA; \\ e-mail:.jpmi@ksu.edu
}

\begin{abstract}
Key words. Coccinellidae, Adalia bipunctata, Capsicum annuum, development, Myzus persicae, Myzus persicae nicotianae, Nicotiana tabacum, reproduction, tritrophic effects
\end{abstract}

\begin{abstract}
A laboratory study was conducted to examine tritrophic effects on the suitability of the peach-potato aphid, Myzus persicae (Sulzer), and tobacco aphid, Myzus persicae nicotianae (Blackman \& Eastop), as prey for the two spot ladybird, Adalia bipunctata (L.), when the aphids were reared on either sweet pepper or tobacco. Significant host plant-aphid interactions were evident for every component of development (juvenile survival, developmental time, adult mass at emergence) and reproduction (preoviposition period, fecundity, fertility). By almost all measures, the suitability of each aphid species was improved by rearing on its host plant of origin and diminished by rearing on the alternative host plant. The symmetry of the interactions are suggestive of both positive and negative host plant effects on aphid suitability as prey. Whereas M. p. nicotianae may be better able than M. persicae to detoxify the nicotine that is likely responsible for the reduced suitability of $M$. persicae when reared on tobacco, it appears to have lower nutritive value for $A$. bipunctata than $M$. persicae when reared on pepper. Thus, population parameters $\left(\mathrm{R}_{0}, \mathrm{r}_{\mathrm{m}}, \lambda\right.$ and DT) derived from performance data indicated that $M$. persicae reared on sweet pepper was the most suitable prey and that the same species reared on tobacco was the least suitable, with other host plant-aphid combinations intermediate.
\end{abstract}

\section{INTRODUCTION}

Although aphidophagous lady beetles are generally polyphagous and consume most of the aphid species that they encounter (Hodek, 1996), aphid species vary in suitability as prey, i.e., the degree to which they support successful development and reproduction (Obrycki \& Orr, 1990; Phoofolo \& Obrycki, 1997; Kalushkov, 1998; Kalushkov \& Hodek, 2004; Mignault et al., 2006). In addition, the speed of coccinellid development and the fecundity and fertility of adult females may vary significantly among prey species that do support complete life histories (Hodek, 1996; Michaud, 2000; Cabral et al., 2006). A further layer of complexity arises via tritrophic interactions (sensu Price et al., 1980) as the host plant may influence the nutritional quality of aphid prey for predators that consume them (Blackman, 1967; Hodek, 1993; Rü \& Mitsipa, 2000; Francis et al., 2001a; Giles et al., 2002a, b; Vanhaelen et al., 2002; Wu et al., 2010).

The two-spotted ladybird, Adalia bipunctata (L.), is a generalist aphidophagous ladybird with a wide prey range (Hodek, 1996; Kalushkov, 1998). Use of this species as a biological control agent on various agricultural crops is now widespread (Omkar \& Pervez, 2005). In Iran, $A$. bipunctata is one of the most common coccinellid predators in fruit and nut crops, e.g., pistachio gardens (Mehrnejad et al., 2010). A substantial literature exists on the relative suitablity of different aphid species as prey for $A$. bipunctata (see Omkar \& Pervez, 2005), but little is known of how host plants may affect this suitability (e.g.,
Francis et al., 2001a, b). Both the green peach aphid, Myzus persicae (Sulzer), and the tobacco aphid, M. persicae nicotianae (Blackman \& Eastop), are known to support both the development and reproduction of $A$. bipunctata (Lommen et al., 2008; Jalali et al., 2009) and thus qualify as "complete" prey (Michaud, 2005). Myzus persicae is a highly polyphagous aphid and a common greenhouse pest with great economic importance on a variety of crops (van Emden et al., 1969; Barbagallo et al., 2007), whereas the subspecies $M$. p. nicotianae causes serious damage to all types of tobacco (Margaritopoulos et al., 2003).

Sweet pepper, Capsicum annuum L., and tobacco, Nicotiana tabacum L. (Solanaceae), are considered to be optimal host plants for Myzus persicae and M. persicae nicotianae, respectively (Olivares-Donoso et al., 2007). Although both host plants may be colonized by both aphid subspecies, M. p. nicotianae has evolved a degree of specialization on tobacco. Margaritopoulos et al. (2005) found that migrant alatae of $M . p$. nicotianae expressed a preference for tobacco over pepper in various choice and no-choice assays, whereas those of $M$. persicae settled more quickly on pepper and were more inclined to leave tobacco shortly after contact in a nochoice test. Similarly, the performance of each aphid subspecies is measurably reduced by rearing on its reciprocal host plant (Nikolakakis et al., 2003), such that M. persicae is eventually capable of competitive exclusion of $M$. p. nicotianae on pepper (Tapia et al., 2008). The objec-

\footnotetext{
* Corresponding author.
} 
TABLE 1. Stage-specific and total mortality (\%) for immature Adalia bipunctata fed one of two aphid species that were reared on each of two different host plants. Values for total mortality bearing different upper case letters were significantly different between plants for a given aphid species; values bearing different lower case letters were significantly different between aphid species for a given host plant (ANOVA, $\alpha=0.05$ ).

\begin{tabular}{|c|c|c|c|c|c|c|c|c|c|}
\hline \multirow{2}{*}{ Plant } & \multirow{2}{*}{ Prey } & \multicolumn{8}{|c|}{ Developmental stage } \\
\hline & & $\mathrm{n}^{\mathrm{a}}$ & Egg & $\mathrm{L}_{1}$ & $\mathrm{~L}_{2}$ & $\mathrm{~L}_{3}$ & $\mathrm{~L}_{4}$ & Pupa & Total \\
\hline \multirow[b]{2}{*}{ Pepper } & M. persicae & 194 & 19.35 & 3.23 & 0.00 & 3.23 & 0.00 & 8.25 & $34.5 \mathrm{Bb}$ \\
\hline & $\begin{array}{c}\text { M. persicae } \\
\text { nicotianae }\end{array}$ & 132 & 28.48 & 7.15 & 3.22 & 0.00 & 3.31 & 10.84 & $53.0 \mathrm{Aa}$ \\
\hline \multirow[b]{2}{*}{ Tobacco } & M. persicae & 172 & 36.40 & 11.45 & 1.50 & 3.38 & 0.00 & 7.28 & $60.0 \mathrm{~A}$ \\
\hline & $\begin{array}{c}\text { M. persicae } \\
\text { nicotianae }\end{array}$ & 172 & 27.30 & 8.72 & 0.00 & 0.00 & 5.05 & 5.05 & 46.1B \\
\hline$\chi^{2}$ & & & 86.8 & 86.8 & 157.9 & 145.5 & 141.1 & 86.8 & 86.8 \\
\hline
\end{tabular}

a - initial number of eggs.

tive of the present study was to test for tritrophic effects on the suitability of these two aphid subspecies as prey for A. bipunctata. Understanding how tritrophic interactions can affect prey suitability for $A$. bipunctata may improve our ability to gage the efficacy of this species in biological control programs against these and other aphids of economic importance.

\section{MATERIAL AND METHODS}

\section{Plant and insect cultures}

Sweet pepper and tobacco plants were grown from seed in plastic pots $(20 \mathrm{~cm}$ diameter $\times 30 \mathrm{~cm}$ height $)$ containing a $1: 1$ mixture of perlite:vermiculite in a greenhouse at a $25 \pm 2{ }^{\circ} \mathrm{C}$ and a photoperiod of $16 \mathrm{~L}: 8 \mathrm{D}$. Stock laboratory cultures of green peach aphids and tobacco aphids were established on their respective host plants from individuals that were field-collected from the same host plants in Rafsanjan, Iran in 2009 and were reared under the same physical conditions as the plants. Aphids for use as prey in experiments were reared on each host plant in separate climate-controlled growth chambers for at least 2 weeks before being fed to $A$. bipunctata.

A laboratory colony of $A$. bipunctata was initiated in May, 2010, using adults collected from pistachio trees, Pistacio vera L., in Rafsanjan, Iran. Adult ladybirds were maintained in plastic containers $(20 \times 25 \times 10 \mathrm{~cm})$, with ventilation holes in the lid screened with fine cloth mesh and fed with Acyrthosiphon pisum (Harris) on shoots of broad bean, Vicia faba L. The ladybird colony was held in a growth chamber set at $25 \pm 1{ }^{\circ} \mathrm{C}$, $65 \pm 5 \% \mathrm{RH}$ and a $16 \mathrm{~L}: 8 \mathrm{D}$ photoperiod.

\section{Experimental conditions}

The experiments were conducted in a growth chamber set at $27 \pm 1{ }^{\circ} \mathrm{C}, 65 \pm 5 \% \mathrm{RH}$ and a $16 \mathrm{~L}: 8 \mathrm{D}$ photoperiod. Ladybird performance was assessed on all four aphid-plant combinations: M. persicae and $M$. p. nicotianae each reared on either sweet pepper or tobacco under the same physical conditions as the experiment.

\section{Development}

Eggs $(<24 \mathrm{~h}$ old $)$ were collected from the stock culture and placed in an incubator at $27^{\circ} \mathrm{C}$. Upon eclosion, first instar larvae $(<24 \mathrm{~h}$ old $)$ were isolated in plastic Petri dishes $(14 \mathrm{~cm}$ diameter). Each larva was provisioned daily with an ad libitum supply of aphids on a leaf. The leaf petioles of pepper leaves were inserted into an Eppendorf tube $(2 \mathrm{ml}$ volume) filled with water and sealed with parafilm. Due to their size, tobacco leaves were trimmed with scissors to make leaf disks that fit inside
Petri dishes (14 cm diameter) and these were placed upside down on a layer of agar (1\%) to delay wilting. A total of 50 newly-eclosed larvae of $A$. bipunctata were assigned to each aphid/host plant feeding treatment. Development and survival of immature stages was monitored daily and adults were sexed and weighed one day after emergence.

\section{Reproduction}

Newly emerged adults ( $<24 \mathrm{~h}$ old) of $A$. bipunctata from the development experiment were then isolated as pairs in $14-\mathrm{cm}$ Petri dishes under the same physical conditions. Dishes were each provisioned with either a sweet pepper leaf or a leaf disk of tobacco infested with one of the two aphid species, as described above. A minimum of nine pairs in each treatment were selected for oviposition observations on the basis of the female beginning oviposition within one week of emergence. Males that died were replaced with other males from the same rearing treatment. The egg production of each $A$. bipunctata female was removed and counted daily for the first 30 days of adult life. A series of egg clusters laid on days 7, 14, 21 and 28 of the experiment were observed until hatching to estimate fertility.

\section{Statistical analysis}

Data were analyzed by 2-way ANOVA (SPSS, 2006) with aphid species and host plant as fixed factors and, in the case of adult mass, by 3-way ANOVA with gender as an additional factor. When interaction terms were significant, independent variables were analyzed separately by one-way ANOVA. Survivorship was compared pairwise among experimental treatments using a chi-square test. Life table parameters were calculated using the developmental and reproduction data obtained. A VBA-macro for the Jackknife method was used to calculate life table parameters for the first month of adult life as described by Vantornhout et al. (2005) and to calculate net reproductive rate $\left(\mathrm{R}_{0}\right)$, intrinsic rate of population increase $\left(\mathrm{r}_{\mathrm{m}}\right)$, finite rate of increase $(\lambda)$ and doubling time (DT). Mean Jackknife pseudovalues for each treatment were subjected to ANOVA followed by the Tukey-Kramer HSD test to compare life table parameters among aphid-host plant combinations $(\alpha=0.05)$.

\section{RESULTS}

\section{Development}

Stage-specific survival rates of $A$. bipunctata on all host/prey combinations are reported in Table 1. Immature survival rates to adult emergence were greater on $M$. persicae than on $M$. p. nicotianae when the host plant was pepper $\left(\chi^{2}=13.75, \mathrm{p}<0.001\right)$ but the difference was not 
TABLE 2. ANOVA of Adalia bipunctata developmental times when fed on one of two aphid species that were reared on each of two host plants.

\begin{tabular}{|c|c|c|c|}
\hline Source of variation & df & $\mathrm{F}$ & $\mathrm{P}$ \\
\hline Egg & 3 & 12.06 & $<0.001$ \\
\hline Plant & 1 & 0.63 & 0.429 \\
\hline Aphid & 1 & 22.63 & $<0.001$ \\
\hline Plant $\mathrm{X}$ aphid & 1 & 4.31 & 0.038 \\
\hline Error term & 666 & & \\
\hline Larva 1 & 3 & 35.31 & $<0.001$ \\
\hline Plant & 1 & 95.56 & $<0.001$ \\
\hline Aphid & 1 & 2.17 & 0.142 \\
\hline Plant $X$ aphid & 1 & 8.21 & 0.005 \\
\hline Error term & 196 & & \\
\hline Larva 2 & 3 & 9.91 & $<0.001$ \\
\hline Plant & 1 & 2.03 & 0.157 \\
\hline Aphid & 1 & 20.65 & $<0.001$ \\
\hline Plant $\mathrm{X}$ aphid & 1 & 8.89 & 0.003 \\
\hline Error term & 163 & & \\
\hline Larva 3 & 3 & 46.85 & $<0.001$ \\
\hline Plant & 1 & 46.15 & $<0.001$ \\
\hline Aphid & 1 & 51.35 & $<0.001$ \\
\hline Plant $\mathrm{X}$ aphid & 1 & 31.08 & $<0.001$ \\
\hline Error term & 158 & & \\
\hline Larva 4 & 3 & 10.74 & $<0.001$ \\
\hline Plant & 1 & 1.29 & 0.258 \\
\hline Aphid & 1 & 25.60 & $<0.001$ \\
\hline Plant $\mathrm{X}$ aphid & 1 & 2.24 & 0.137 \\
\hline Error term & 143 & & \\
\hline Pupa & 3 & 17.99 & $<0.001$ \\
\hline Plant & 1 & 37.08 & $<0.001$ \\
\hline Aphid & 1 & 1.65 & 0.201 \\
\hline Plant $\mathrm{X}$ aphid & 1 & 18.43 & $<0.001$ \\
\hline Error term & 134 & 5.59 & $<0.001$ \\
\hline Total & 3 & 49.20 & $<0.001$ \\
\hline Plant & 1 & 0.99 & 0.322 \\
\hline Aphid & 1 & 41.72 & $<0.001$ \\
\hline Plant $X$ aphid & 1 & 77.66 & $<0.001$ \\
\hline Error term & 116 & & \\
\hline
\end{tabular}

significant when the host plant was tobacco $\left(\chi^{2}=2.60\right.$, ns). However, rearing the aphid on its host plant of origin improved predator survival whether the prey was M. persicae $\left(\chi^{2}=11.11, \mathrm{P}<0.001\right)$ or $M . p$. nicotianae $\left(\chi^{2}=\right.$ $4.03, \mathrm{p}<0.05)$.

The overall model indicated significant variation in total developmental time with a significant plant-aphid interaction (Table 2, Fig. 1). When the host plant was pepper, development of A. bipunctata was almost 2.5 days faster on M. persicae than on M. p. nicotianae $\left(\mathrm{F}_{1,70}\right.$ $=132.88, \mathrm{p}<0.001)$, but when it was tobacco, development time was intermediate and not significantly different between aphid species $\left(\mathrm{F}_{1,46}=2.70, \mathrm{p}=0.107\right)$. The total developmental time of beetles was shorter when each aphid was reared on its host of origin compared to the alternative plant (M. persicae: $\mathrm{F}_{1,64}=32.37, \mathrm{p}<0.001 ; M$. p. nicotianae: $\left.\mathrm{F}_{1,70}=46.37, \mathrm{p}<0.001\right)$.

Stage-specific developmental times of A. bipunctata on all host/prey combinations are reported in Table 3. The 2-way ANOVA of egg hatching time was significant and indicated a significant plant-aphid interaction (Table 2). Eggs hatched faster on the $M$. persicae diet when aphids

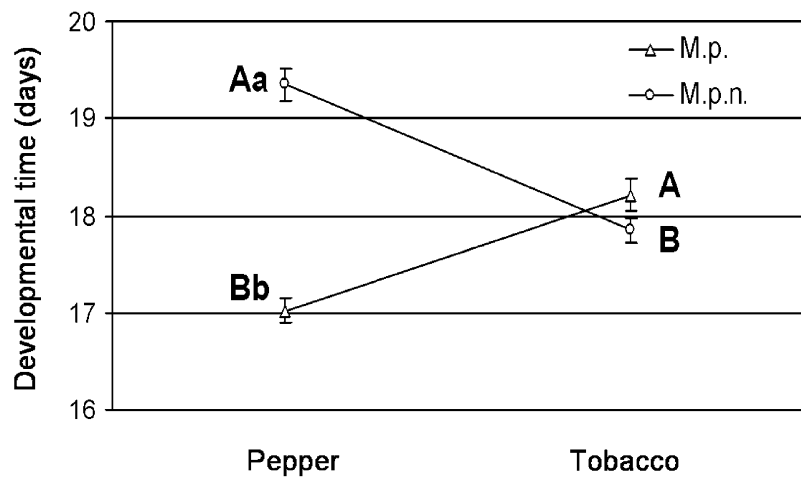

Fig. 1. Mean larval developmental times ( $\pm \mathrm{SE}$ ) from first instar to adult of $A$. bipunctata when fed on either M. persicae (M.p.) or M. p. nicotianae (M.p.n.) that were reared on each of two host plants. Different lower case letters indicate significant differences (ANOVA, $\alpha=0.05$ ) between aphid species reared on the same host plant; different upper case letters indicate significant differences between host plants for a particular aphid species.

were reared on pepper $\left(\mathrm{F}_{1,364}=25.48, \mathrm{p}<0.001\right)$ but the difference was not significant on tobacco $\left(\mathrm{F}_{1,302}=3.34\right.$, $\mathrm{P}$ $=0.069$ ). Eclosion time did not vary with host plant when M. p. nicotianae were prey $\left(\mathrm{F}_{1,245}=0.47, \mathrm{p}=0.493\right)$, but was faster on pepper when $M$. persicae were prey $\left(\mathrm{F}_{1,421}=\right.$ $7.22, \mathrm{p}=0.007)$. The first larval instar also varied significantly in duration among treatments with a significant plant-aphid interaction. Larvae of A. bipunctata molted to the second instar faster when prey were reared on pepper than on tobacco (M. persicae: $\mathrm{F}_{1,98}=89.08, \mathrm{p}<0.001 ; M$. p. nicotianae: $\left.\mathrm{F}_{1,98}=21.64, \mathrm{p}<0.001\right)$, and faster feeding on M. persicae than on M. p. nicotianae when the host plant was pepper $\left(\mathrm{F}_{1,98}=30.43, \mathrm{p}<0.001\right)$, but not when it was tobacco $\left(\mathrm{F}_{1,98}=0.57, \mathrm{p}=0.450\right)$. There was also significant variation in duration of the second instar with a significant plant-aphid interaction. The second instar was shorter for $A$. bipunctata larvae feeding on $M$. $p$. nicotianae than on $M$. persicae when the host plant was tobacco $\left(\mathrm{F}_{1,73}=22.89, \mathrm{p}<0.001\right)$ but the difference was not significant on pepper $\left(\mathrm{F}_{1,90}=1.51, \mathrm{p}=0.223\right)$. Rearing aphids on tobacco increased the duration of the second instar when the prey was M. persicae $\left(\mathrm{F}_{1,98}=7.05, \mathrm{p}=\right.$ $0.009)$ but not when it was M. p. nicotianae $\left(\mathrm{F}_{1,77}=2.36\right.$, $\mathrm{p}=0.128)$.

The 2-way model was significant for variation in duration of the third instar with a significant plant-aphid interaction. Duration of the third instar was shorter on $M$. persicae that on $M$. p. nicotianae when the aphid host plant was pepper $\left(\mathrm{F}_{1,90}=16.81, \mathrm{p}<0.001\right)$, but not different when it was tobacco $\left(\mathrm{F}_{1,68}=1.74, \mathrm{p}=0.191\right)$. Rearing on pepper increased the duration of the third instar relative to rearing on tobacco when the prey was $M$. p. nicotianae $\left(\mathrm{F}_{1,72}=60.29, \mathrm{p}<0.001\right)$ but not when it was M. persicae $\left(\mathrm{F}_{1,86}=0.95, \mathrm{p}=0.333\right)$. For duration of the fourth instar, the overall model was significant but the plant-aphid interaction was not. Host plant did not affect the duration of the fourth instar whether the prey was $M$. persicae $\left(\mathrm{F}_{1,81}=0.07, \mathrm{p}=0.792\right)$ or M. p. nicotianae $\left(\mathrm{F}_{1,62}\right.$ 
TABLE 3. Developmental times for immature Adalia bipunctata fed one of two aphid species that were reared on each of two host plants. Values bearing different upper case letters were significantly different between plants for a given aphid species; values bearing different lower case letters were significantly different between aphid species for a given host plant (ANOVA, $\alpha=0.05$ ).

\begin{tabular}{lccccccc}
\hline \multirow{2}{*}{ Plant } & \multirow{2}{*}{ Prey } & \multicolumn{5}{c}{ Developmental time (days) } \\
\cline { 3 - 8 } & & Egg & Larva 1 & Larva 2 & Larva 3 & Larva 4 & Pupa \\
\hline \multirow{2}{*}{ Pepper } & M. persicae & $3.09 \pm 0.02 \mathrm{a}$ & $1.98 \pm 0.03 \mathrm{Bb}$ & $1.30 \pm 0.07 \mathrm{~B}$ & $2.02 \pm 0.07 \mathrm{~b}$ & $3.03 \pm 0.06 \mathrm{~b}$ & $5.57 \pm 0.07 \mathrm{~b}$ \\
& M. p. nicotianae & $3.30 \pm 0.05 \mathrm{~b}$ & $2.34 \pm 0.06 \mathrm{Ba}$ & $1.19 \pm 0.05$ & $2.87 \pm 0.07 \mathrm{Aa}$ & $3.70 \pm 0.10 \mathrm{a}$ & $6.10 \pm 0.07 \mathrm{Aa}$ \\
\hline \multirow{2}{*}{ Tobacco } & M. persicae & $3.18 \pm 0.03$ & $3.03 \pm 0.11 \mathrm{~A}$ & $1.60 \pm 0.09 \mathrm{Aa}$ & $1.93 \pm 0.04$ & $3.07 \pm 0.13 \mathrm{~b}$ & $5.40 \pm 0.08$ \\
& M. p. nicotianae & $3.26 \pm 0.03$ & $2.92 \pm 0.11 \mathrm{~A}$ & $1.09 \pm 0.05 \mathrm{~b}$ & $2.04 \pm 0.08 \mathrm{~B}$ & $3.43 \pm 0.11 \mathrm{a}$ & $5.11 \pm 0.17 \mathrm{~B}$ \\
\hline
\end{tabular}

$=3.39, \mathrm{p}=0.071)$. However, the fourth instar was completed faster on $M$. persicae than on $M . p$. nicotianae on both host plants, the magnitude of the difference being greater on pepper $\left(\mathrm{F}_{1,82}=36.86, \mathrm{p}<0.001\right)$ than on tobacco $\left(\mathrm{F}_{1,62}=3.88, \mathrm{p}=0.053\right)$. There was significant variation overall in duration of the pupal stage with a significant plant-aphid interaction. Pupation was completed faster on $M$. persicae than on $M$. $p$. nicotianae when the aphid host plant was pepper $\left(\mathrm{F}_{1,78}=26.16, \mathrm{p}<0.001\right)$, but not when it was tobacco $\left(\mathrm{F}_{1,56}=2.77, \mathrm{p}=0.201\right)$. Rearing M. p. nicotianae on tobacco reduced $A$. bipunctata pupation time relative to rearing it on pepper $\left(\mathrm{F}_{1,59}=35.99, \mathrm{p}<\right.$ $0.001)$, but there was no effect of host plant when the prey was $M$. persicae $\left(\mathrm{F}_{1,75}=2.50, \mathrm{p}=0.118\right)$.

Since females were consistently larger than males regardless of diet (mean $\pm \mathrm{SE}=12.6 \pm 0.19$ vs. $9.7 \pm 0.13$ $\mathrm{mg}$, respectively), the two sexes were analyzed separately for adult fresh mass. A 2-way ANOVA for female mass was not significant overall, but the plant-aphid interaction

TABLE 4. ANOVA of body mass at emergence and reproductive parameters for female Adalia bipunctata fed one of two aphid species that were reared on each of two host plants.

\begin{tabular}{lrrr}
\hline Source of variation & df & \multicolumn{1}{c}{$\mathrm{F}$} & \multicolumn{1}{c}{$\mathrm{P}$} \\
\hline Fresh mass & 3 & 2.41 & 0.082 \\
$\quad$ Plant & 1 & 1.78 & 0.190 \\
Aphid & 1 & 0.10 & 0.756 \\
Plant X aphid & 1 & 5.72 & 0.022 \\
$\quad$ Error term & 37 & & \\
Preoviposition period & 3 & 5.80 & 0.001 \\
Plant & 1 & 95.56 & $<0.001$ \\
Aphid & 1 & 2.17 & 0.142 \\
Plant X aphid & 1 & 8.21 & 0.005 \\
Error term & 37 & & \\
Fecundity & 3 & 4.52 & 0.008 \\
Plant & 1 & 0.28 & 0.600 \\
Aphid & 1 & 0.54 & 0.468 \\
Plant X aphid & 1 & 12.79 & 0.001 \\
Error term & 37 & & \\
Fertility & 3 & 65.36 & $<0.001$ \\
Plant & 1 & 46.15 & $<0.001$ \\
Aphid & 1 & 51.35 & $<0.001$ \\
Plant X aphid & 1 & 184.37 & $<0.001$ \\
Error term & 116 & & \\
\hline
\end{tabular}

was (Table 4). Females attained larger mass on M. persicae when it was reared on pepper compared with tobacco $\left(\mathrm{F}_{1,17}=6.27, \mathrm{p}=0.023\right)$ but there was no host plant effect when feeding on $M$. $p$. nicotianae $\left(\mathrm{F}_{1,20}=\right.$ $0.62, \mathrm{p}=0.440)$ and not significant effect of aphid species on either plant (pepper: $\mathrm{F}_{1,19}=3.98, \mathrm{p}=0.061$; tobacco: $\left.\mathrm{F}_{1,18}=1.99, \mathrm{p}=0.0176\right)$. The overall model was also significant for male mass $\left(\mathrm{F}_{3,56}=13.93, \mathrm{p}<0.001\right)$ with a significant plant-aphid interaction $\left(\mathrm{F}_{1,56}=26.31, \mathrm{p}\right.$ $<0.001)$. Males gained more mass on each aphid species when it was reared on its host plant of origin $(M$. persicae: $\mathrm{F}_{1,28}=22.42, \mathrm{p}<0.001 ;$ M. p. nicotianae: $\mathrm{F}_{1,28}=$ $18.71, \mathrm{p}<0.001)$ and rearing prey on the alternative host plant reduced the suitability of both aphids relative to rearing on their host plant of origin $\left(M\right.$. persicae: $\mathrm{F}_{1,28}=$ $26.76, \mathrm{p}<0.001 ;$ M. p. nicotianae: $\mathrm{F}_{1,28}=14.20, \mathrm{p}=$ $0.001)$.

\section{Reproduction}

Mean fresh massses and reproductive parameters for $A$. bipunctata females reared on all host/prey combinations are reported in Table 5. The 2-way ANOVA was significant for variation in length of the preoviposition period and the plant-aphid interaction was significant (Table 4). Females started laying eggs sooner on $M$. persicae if it was reared on pepper instead of tobacco $\left(\mathrm{F}_{1,17}=5.88, \mathrm{p}=\right.$ 0.027 ) and sooner on $M$. p. nicotianae if it was reared on tobacco instead of pepper $\left(\mathrm{F}_{1,20}=13.51, \mathrm{p}=0.001\right)$. Similarly, preoviposition periods were shorter on $M$. persicae than on $M$. p. nicotianae when the host plant was pepper $\left(\mathrm{F}_{1,19}=6.59, \mathrm{p}=0.019\right)$ and shorter on $M . p$. nicotianae than on $M$. persicae when the host plant was tobacco $\left(\mathrm{F}_{1,19}=16.02, \mathrm{p}=0.001\right)$. The overall model was also significant for effects on fecundity (no. eggs laid during the first 30 days of adult life) as was the plant-aphid interaction (Table 4). Fecundity was higher on M. persicae than on $M$. p. nicotianae when pepper was the host plant $\left(\mathrm{F}_{1,19}\right.$ $=9.66, \mathrm{p}=0.006)$ but the inverse effect on tobacco was not quite significant $\left(\mathrm{F}_{1,18}=3.89, \mathrm{p}=0.064\right)$. However, rearing on the alternative host plant significantly reduced the suitability of both species compared to rearing on their host plant of origin (M. persicae: $\mathrm{F}_{1,17}=5.04, \mathrm{p}=$ $0.038 ;$ M. p. nicotianae: $\left.\mathrm{F}_{1,20}=9.50, \mathrm{p}=0.006\right)$.

The 2-way ANOVA was significant for egg fertility and the plant-aphid interaction was significant (Table 4). Fertility was higher on pepper than on tobacco when the prey was $M$. persicae $\left(\mathrm{F}_{1,30}=162.65, \mathrm{p}<0.001\right)$ and higher on tobacco than on pepper when the prey was $M$. 
TABLE 5. Comparative body sizes and reproductive parameters of Adalia bipunctata females reared on one of two aphid species that were reared on each of two host plants. Different upper case letters indicate significant differences between host plants for a particular aphid species; different lower case letters indicate significant differences between aphid species for a particular host plant (ANOVA, $\alpha=0.05$ ).

\begin{tabular}{lccccc}
\hline Plant & Prey & Fresh mass $(\mathrm{mg})$ & Preoviposition period (days) & Fecundity (no. eggs) & Fertility (\% hatching) \\
\hline \multirow{2}{*}{ Pepper } & M. persicae & $13.30 \pm 0.37 \mathrm{~A}$ & $5.30 \pm 0.34 \mathrm{Bb}$ & $798 \pm 78 \mathrm{Aa}$ & $88.1 \pm 1.2 \mathrm{Aa}$ \\
& M. p. nicotianae & $12.30 \pm 0.34$ & $6.27 \pm 0.20 \mathrm{Aa}$ & $516 \pm 49 \mathrm{Bb}$ & $59.5 \pm 2.5 \mathrm{Bb}$ \\
\hline \multirow{2}{*}{ Tobacco } & M. persicae & $11.92 \pm 0.41 \mathrm{~B}$ & $6.22 \pm 0.15 \mathrm{Aa}$ & $529 \pm 91 \mathrm{~B}$ & $64.9 \pm 1.4 \mathrm{Bb}$ \\
& M. p. nicotianae & $12.69 \pm 0.36$ & $5.36 \pm 0.15 \mathrm{Bb}$ & $716 \pm 42 \mathrm{~A}$ & $82.0 \pm 1.3 \mathrm{Aa}$ \\
\hline
\end{tabular}

p. nicotianae $\left(\mathrm{F}_{1,30}=63.08, \mathrm{p}<0.001\right)$. Rearing M. persicae on tobacco reduced $A$. bipunctata fertility relative to rearing it on pepper $\left(\mathrm{F}_{1,30}=106.65, \mathrm{p}<0.001\right)$ and rearing $M$. p. nicotianae on pepper reduced $A$. bipunctata fertility relative to rearing it on tobacco $\left(\mathrm{F}_{1,30}=79.47, \mathrm{p}<\right.$ $0.001)$.

Based upon life table analysis, the $M$. persicae reared on tobacco had the lowest nutritional quality for $A$. bipunctata and $M$. persicae reared on pepper the highest (Table 6). Net reproductive rate $\left(\mathrm{R}_{\mathrm{o}}\right)$, intrinsic rate of increase $\left(r_{m}\right)$, and finite rate of increase $(\lambda)$ were all highest for ladybirds fed $M$. persicae reared on sweet pepper and lowest for those fed $M$. persicae on tobacco, and population doubling time (DT) was the shortest and longest, respectively, on these aphid-host plant combinations.

\section{DISCUSSION}

Survival of immature $A$. bipunctata to adult emergence was significantly better when each prey aphid was reared on its host plant of origin than on the reciprocal host plant, and each aphid species yielded higher immature beetle survival than the other when reared on its host plant of origin. Although the nature of the interaction between host plant and aphid species varied somewhat among life stages of $A$. bipunctata, the suitability of prey as reflected in total developmental time followed the same pattern as that of survival (Fig. 1). In both cases, the magnitude of the differences were greater between aphid species on pepper than on tobacco (developmental time: $>$ 2 days vs $<$ one day and survival: $36 \%$ vs $16 \%$ ). Similarly, male beetles emerged as adults with larger body masses when their prey fed on its preferred host, although the effect was not significant for female beetles.
Data on reproductive performance further supported the preferred host effect on aphid suitability, with the exception of fecundity on tobacco which was not significantly different between aphid subspecies. In addition, all derived population parameters indicated that rates of $A$. bipunctata population growth would be higher when prey were reared on their host of origin and lower on the reciprocal host.

A combination of positive (nutritive) and negative (toxic) tritrophic effects may account for these results. When feeding on plants that contain toxic metabolites, aphids may accumulate them and thus become toxic prey for predators (Hodek, 1960; Canard, 1977; Malcolm 1990). For example, Francis et al. (2000, 2001a, b) showed than $M$. persicae suitability as prey for $A$. bipunctata was reduced when the aphid was reared on Brassica spp. with elevated levels of glucosinolates. Similar results were obtained by Pratt et al. (2008) who fed A. bipunctata and Coccinella septempunctata L. with Brevicoryne brassicae (L.) reared on diets with varying levels of sinigrin; higher levels had greater negative impact on the former species. One obvious contrast between the two host plants employed in this study is the presence of nicotine in tobacco that has insecticidal activity against aphids (Thurston et al., 1966) and the lack of any analogous allelochemicals in pepper. Cabrera-Brandt et al. (2010) demonstrated that M. p. nicotianae exhibits elevated levels of esterase activity after rearing on tobacco for $48 \mathrm{~h}$ and inferred the involvement of these enzymes in the detoxification of nicotine. However, our results revealed more symmetric aphid-host plant interactions that cannot be solely explained by plant-derived allelochemicals present in one host plant. Overall, the best immature survival and development was obtained with $M$. persicae reared on

TABLE 6. Mean ( \pm SE) life table parameters of female Adalia bipunctata fed on two aphid species that were reared on each of two different host plants. $\mathrm{R}_{0}=$ net reproductive rate (females/female), $\mathrm{r}_{\mathrm{m}}=$ intrinsic rate of increase (females/female/day), $\lambda=$ finite rate of increase (females/female/day), DT = doubling time (days). Means bearing the same letter were not significantly different within columns (Tukey-Kramer HSD test, $\alpha=0.05$ ).

\begin{tabular}{|c|c|c|c|c|c|c|}
\hline \multirow{2}{*}{ Host plant } & \multirow{2}{*}{ Prey } & \multirow{2}{*}{$\mathrm{n}$} & \multicolumn{4}{|c|}{ Life table parameter } \\
\hline & & & $\mathrm{R}_{0}$ & $\mathrm{r}_{\mathrm{m}}$ & $\lambda$ & DT \\
\hline \multirow{2}{*}{ Pepper } & M. persicae & 10 & $383.0 \pm 0.5 \mathrm{a}$ & $0.194 \mathrm{a}$ & $1.214 \mathrm{a}$ & $3.57 \mathrm{~d}$ \\
\hline & M. persicae nicotianae & 11 & $233.1 \pm 2.3 \mathrm{c}$ & $0.173 \mathrm{c}$ & $1.189 \mathrm{c}$ & $4.01 \mathrm{~b}$ \\
\hline \multirow{2}{*}{ Tobacco } & M. persicae & 9 & $217.0 \pm 3.7 \mathrm{~d}$ & $0.166 \mathrm{~d}$ & $1.180 \mathrm{~d}$ & $4.18 \mathrm{a}$ \\
\hline & M. persicae nicotianae & 11 & $345.5 \pm 1.8 b$ & $0.178 \mathrm{~b}$ & $1.194 b$ & $3.90 \mathrm{c}$ \\
\hline $\mathrm{F}$ & & & 803.18 & 1850.44 & 1885.05 & 1493.5 \\
\hline
\end{tabular}


pepper, possibly because some nicotine residues remained in both aphid species when reared on tobacco, even though M. p. nicotianae may have detoxified it more effectively.

Although nicotine residues could account for the reduction in suitability of $M$. persicae on tobacco relative to pepper, it cannot account for the reduction in suitability of $M$. p. nicotianae on pepper and host plant-derived differences in aphid nutritional content would seem implicated. There is evidence to suggest that specialization on tobacco has compromised the ability of $M$. p. nicotianae to utilize pepper, and this may account for its reduced nutritional quality when reared on the latter. For example, Nikolakakis et al. (2003) found that M. persicae clones from tobacco-growing regions of Greece had lower performance parameters and adult weights when reared on pepper, whereas the reverse was true for clones obtained from non tobacco-producing regions. Likewise, Riddick et al. (2011) demonstrated that larvae of Stethorus punctillum (Weise) experienced delayed development when foraging on two-spotted spider mites, Tetranychus urticae Koch, that were reared on Phaseolus lunatus L. (cv. Henderson) and correlated this with elevated concentrations of a cyanogenic glycoside that appeared to impede the mite's ability to utilize plant protein. Aphid size alone may affect the foraging efficiency of aphidophagous larvae, and thus their developmental rates (Roger et al., 2000; Michaud, 2001). Although Giles et al. (2002a) found no significant effect of alfalfa cultivar, Medicago sativa, on the suitability of Acyrthosiphum kondoi as prey for either Hippodamia convergens Guerin-Meneville or C. septempunctata, Giles et al. (2002b) found that rearing Acyrthosiphum pisum Harris on alfalfa improved its suitability as prey for $C$. septempunctata compared to rearing it on Vicia faba L., an effect the authors attributed to greater lipid storage by the aphids when feeding on the former plant. Similarly, Wu et al. (2010) observed subtle differences in the suitability of Aphis gossypii Glover as prey for Hippodamia variegata (Goeze) across five cucurbitaceous host plants; observed differencies were attributed to nutritional differences. Thus, there exists a trend for aphids to be more suitable and nutritious prey for coccinellid predators when they are reared on a more suitable host plant.

Morphologically, the leaves of pepper are relatively glabrous whereas those of tobacco are hirsute and covered with dense trichomes. Both structural and biochemical properties of tobacco leaves have been shown to affect the searching efficiency of aphidophagous larvae, including coccinellids (Carter et al., 1984). For example, Belcher \& Thurston (1982) found that the searching speed of $H$. convergens larvae was inversely dependent on the density of glandular trichomes on tobacco leaves. Similar results were observed for early instar larvae of the common green lacewing, Chrysoperla carnea (Stephens) (Neuroptera: Chrysopidae), the twelve spotted lady beetle, Coleomegilla maculata (De Geer) (Elsey, 1974) and A. bipunctata (Shah, 1982). Riddick \& Wu (2011) demonstrated that the density of hooked trichomes pre- sent on leaves of $P$. lunatus (cv. Henderson) was negatively correlated with the survival of $S$. punctillum larvae foraging for two-spotted spider mites. Thus, leaf surface structure may have been responsible for the somewhat higher larval mortality on tobacco and may have also contributed to the generally lower performance of $\mathrm{A}$. bipunctata larvae foraging on tobacco-reared aphids in our study if it impeded rates of prey consumption.

The results of this study demonstrate the potential of tritrophic interactions to affect predator performance and population growth parameters and illustrate not only the importance of carefully selecting host plant-aphid combinations to optimize the mass-rearing of coccinellids for biological control programs, but also why coccinellid numerical responses, and thus levels of biological control, may vary among agricultural crops bearing the same aphid species.

ACKNOWLEDGEMENTS. The authors wish to thank M.R. Mehrnejad of the Pistachio Research Institute of Iran for supplying specimens of $A$. bipunctata used to initiate the colony and the Department of Plant Protection, Vali-e-Asr University of Rafsanjan for providing greenhouse facilities. Thanks are also due to master students of the entomology program at Valie-Asr University for their assistance with collection and rearing of the aphids.

\section{REFERENCES}

Barbagallo S., Cocuzza G., Cravedi P. \& Komazaki S. 2007: IPM case studies: deciduous fruit trees. In van Emden H.F. \& Harrington R. (eds): Aphids as Crop Pests. CABI International, Wallingford, Oxon, pp. 651-676.

BELCHER D.W. \& ThURSTON R. 1982: Inhibition of movement of larvae of the convergent lady beetle by leaf trichomes of tobacco. Environ. Entomol. 11: 91-94.

Blackman R.L. 1967: The effects of different aphid foods on Adalia bipunctata L. and Coccinella septempunctata L. Ann. Appl. Biol. 59: 207-219.

Cabral S., Soares A.O., Moura R. \& Garcia P. 2006: Suitability of Aphis fabae, Myzus persicae (Homoptera: Aphididae) and Aleyrodes proletella (Homoptera: Aleyrodidae) as prey for Coccinella undecimpunctata (Coleoptera: Coccinellidae). Biol. Contr. 39: 434-440.

Cabrera-Brandt M.A., Fuentes-Contreras E. \& Figueroa C.C. 2010: Differences in the detoxification metabolism between two clonal lineages of the aphid Myzus persicae (Sulzer) (Hemiptera: Aphididae) reared on tobacco (Nicotiana tabacum L.). Chil. J. Agric. Res. 70: 567-575.

CANARD M. 1977: Diminished survival rate of the predator Chrysopa perla (L.) in relation to behavior of the aphid Aphis nerii B. de F. (Homoptera: Aphididae). In Medioni J. \& Boseiger E. (eds): Mecanismes Ethologique de l'Evolution. Masson, Paris, pp. 49-51.

Carter M., Sutherland D. \& Dixon A.F.G. 1984: Plant structure and the searching efficiency of coccinellid larvae. Oecologia 63: 394-397.

ElSEY K. 1974: Influence of plant host on searching speed of two predators. BioControl 19: 3-6.

EMden H.F. van, Eastop V.F., Hughes R.D. \& Way M.J. 1969: The ecology of Myzus persicae. Annu. Rev. Entomol. 14: 197-270.

Francis F., Haubruge E., Defrance T. \& Gaspar C. 2000: Environmentally based maternal effect on reproduction of Adalia 
bipunctata: impact of aphid prey species. Med. Fac. Landbouw. Toegep. Biol. Wetensch. Univ. Gent 65: 303-310.

Francis F., Haubruge E., Defrance T. \& Gaspar C. 2001a: Effect of aphid host plant on development and reproduction of the third trophic level, the predator Adalia bipunctata (Coleoptera: Coccinellidae). Environ. Entomol. 30: 947-952.

Francis F., Lognay G., Wathelet J.P. \& Haubruge E. 2001b: Effects of allelochemicals from first (Brassicaceae) and second (Myzus persicae and Brevicoryne brassicae) trophic levels on Adalia bipunctata. J. Chem. Ecol. 27: 243-256.

Giles K.L., Berberet R.C., Zarrabi A.A. \& Dillwith J.W. 2002a: Influence of alfalfa cultivar on suitability of Acyrthosiphon kondoi (Homoptera: Aphididae) for survival and development of Hippodamia convergens and Coccinella septempunctata (Coleoptera: Coccinellidae). J. Econ. Entomol. 95: 552-557.

Giles K.L., Madden R.D., Stockland R., Payton M.E. \& DillWITH J.W. 2002b: Host plants affect predator fitness via the nutritional value of herbivore prey: investigation of a plantaphid-ladybeetle system. BioControl 47: 1-21.

Hodek I. 1960: The influence of various aphid species as food for two ladybirds, Coccinella septempunctata L. and Adalia bipunctata L. In The Ontogeny of Insects (Proc. Symp. Prague, 1959). Academia, Prague, pp. 314-316.

HoDEK I. 1993: Habitat and food specificity in aphidophagous predators. Biocontr. Sci. Tech. 3: 91-100.

Hodek I. 1996: Food relations. In Hodek I. \& Honek A. (eds): Ecology of Coccinellidae. Kluwer, Dordrecht, pp. 143-238.

Jalali M.A., Tirry L. \& De Clerce P. 2009: Effects of food and temperature on development, fecundity and life table parameters of Adalia bipunctata (Coleoptera: Coccinellidae). J. Appl. Entomol. 133: 615-625.

KalushKov P. 1998: Ten aphid species (Sternorrhyncha: Aphididae) as prey for Adalia bipunctata (Coleoptera: Coccinellidae). Eur. J. Entomol. 95: 343-349.

Kalushrov P. \& HodeK I. 2004: The effects of thirteen species of aphids on some life history parameters of the ladybird Coccinella septempunctata. BioControl 49: 21-32.

Lommen S.T.E., Middendorp C.W., LuiJten C.A., Van Schelt J., BRakefield P.M. \& De Jong P.W. 2008: Natural flightless morphs of the ladybird beetle Adalia bipunctata improve biological control of aphids on single plants. Biol. Contr. 47: 340-346.

Malcolm S.B. 1990: Chemical defence in chewing and sucking insect herbivores: Plant-derived cardenolides in the monarch butterfly and oleander aphid. Chemoecology 1: 12-21.

Margaritopoulos J.T., Tsitsipis J.A. \& Perdikis D.C. 2003: Biological characteristics of the mirids Macrolophus costalis and Macrolophus pygmaeus preying on the tobacco form of Myzus persicae (Hemiptera: Aphididae). Bull. Entomol. Res. 93: 39-45.

Margaritopoulos J.T., Tsourapas C., Tzortzi M., Kanavaki O.M. \& Tsitsipis J.A. 2005: Host selection by winged colonizers within the Myzus persicae group: a contribution toward understanding host specialization. Ecol. Entomol. 30: 406-418.

Mehrnejad M.R., Jalali M.A. \& Mirzaei R. 2010: Abundance and biological parameters of psyllophagous coccinellids in pistachio orchards. J. Appl. Entomol. 135: 673-681.

Michaud J.P. 2000: Development and reproduction of ladybeetles (Coleoptera: Coccinellidae) on the citrus aphids Aphis spiraecola Patch and Toxoptera citricida (Kirkaldy) (Homoptera: Aphididae). Biol. Contr. 18: 287-297.

Michaud J.P. 2001: Evaluation of green lacewings, Chrysoperla plorabunda (Fitch) (Neurop.: Chrysopidae) for augmentative release against Toxoptera citricida (Hom.: Aphididae) in citrus. J. Appl. Entomol. 125: 383-388.

Michaud J.P. 2005: On the assessment of prey suitability in aphidophagous Coccinellidae. Eur. J. Entomol. 102: 385-390.

Mignault M.P., Roy M. \& Brodeur J. 2006: Soybean aphid predators in Quebec and the suitability of Aphis glycines as prey for three Coccinellidae. BioControl 51: 89-106.

Nikolakakis N., Margaritopoulos J. \& Tsitsipis J. 2003: Performance of Myzus persicae (Hemiptera: Aphididae) clones on different host-plants and their host preference. Bull. Entomol. Res. 93: 235-242.

OBRYCKI J.J. \& ORR C.J. 1990: Suitability of three prey species for Nearctic populations of Coccinella septempunctata, Hippodamia variegata, and Propylea quatuordecimpunctata (Coleoptera: Coccinellidae). J. Econ. Entomol. 83: 1292-1297.

Olivares-Donoso R., Troncoso A., Tapia D., AguileraOlivares D. \& NiEMEYER H. 2007: Contrasting performances of generalist and specialist Myzus persicae (Hemiptera: Aphididae) reveal differential prevalence of maternal effects after host transfer. Bull. Entomol. Res. 97: 61-67.

Omkar P.A. \& Pervez A. 2005: Ecology of two-spotted ladybird, Adalia bipunctata: a review. J. Appl. Entomol. 129: 465-474.

Phoofolo M.W. \& ObRYCKi J.J. 1997: Comparative prey suitability of Ostrinia nubilalis eggs and Acyrthosiphon pisum for Coleomegilla maculata. Biol. Contr. 9: 167-172.

Pratt C., Pope T.W., Powell G. \& Rossiter J.T. 2008: Accumulation of glucosinolates by the cabbage aphid Brevicoryne brassicae as a defense against two coccinellid species. $J$. Chem. Ecol. 34: 323-329.

Price P.W., Bouton C.E., Gross P., McPheron B.A., Thompson J.N. \& WeIS A.E. 1980: Interactions among three trophic levels: influence of plants on interactions between insect herbivores and natural enemies. Annu. Rev. Ecol. Syst. 11: 41-65.

RidDick E.W. \& WU Z. 2011: Lima bean - lady beetle interactions: hooked trichomes affect survival of Stethorus punctillum larvae. BioControl 56: 55-63.

Riddick E.W., RoJAs M.G. \& Wu Z. 2011: Lima bean - lady beetle interactions: spider mite mediates sublethal effects of its host plant on growth and development of its predator. Arth. Plant Int. 5: 287-296.

Roger C., Coderre D. \& Boivin G. 2000: Differential prey utilization by the generalist predator Coleomegilla maculata lengi according to prey size and species. Entomol. Exp. Appl. 94: 3-13.

RÜ B.L. \& Mitsipa A. 2000: Influence of the host plant of the cassava mealybug, Phenacoccus manihoti, on life-history parameters of the predator Exochomus flaviventris. Entomol. Exp. Appl. 95: 209-212.

Sнан M.A. 1982: The influence of plant surfaces on the searching behaviour of coccinellid larvae. Entomol. Exp. Appl. 31: 377-380.

SPSS InstituTE 2006: SPSS Base 15.0 for Windows, User's Guide Computer Program Version by SPSS Inc., Chicago, IL.

Tapia D.H., Troncoso A.J., Vargas R.R., Olivares-Donoso R. \& NiEMEYER H.M. 2008: Experimental evidence for competitive exclusion of Myzus persicae nicotianae by Myzus persicae (Hemiptera: Aphididae) on sweet pepper, Capsicum annuum (Solanaceae). Eur. J. Entomol. 105: 643-648.

THOMPSON J.N. 1988: Coevolution and alternative hypotheses on insect plant interactions. Ecology 69: 893-895. 
Thurston R., Smith W.T. \& Cooper B.P. 1966: Alkaloid secretion by trichomes of Nicotiana species and resistance to aphids. Entomol. Exp. Appl. 9: 428-432.

Vanhaelen N., Gaspar C. \& Francis F. 2002: Influence of prey host plant on a generalist aphidophagous predator: Episyrphus balteatus (Diptera: Syrphidae). Med. Fac. Landbouw. Toegep. Biol. Wetensch. Univ. Gent 67: 563-568.
Vantornhout I., Minnaert H.L., Tirry L. \& De Clerce P. 2005: Influence of diet on life table parameters of Iphiseius degenerans (Acari: Phytoseiidae). Exp. Appl. Acarol. 35: 183-195.

Wu X.H., Zhou X.R. \& PANG B.P. 2010: Influence of five host plants of Aphis gossypii Glover on some population parameters of Hippodamia variegata (Goeze). J. Pest Sci. 83: 77-83.

Received December 31, 2011; revised and accepted February 29, 2012 